\title{
染料中間物の廃水処理における諸問題
}

\author{
石 川 洋 介* \\ A few Proposals to Solve Economical Problems on the Treatment of \\ Waste Water in the Dyestuff's Intermediates Industry
}

Yohsuke IsHikawA*

化学工業注公害発生源の親玉として，現代の悪党の役 を押しつけられている。事実, 大気污染, 水質污濁, 墨 臭, 騒音など, どれをとっても決して善玉の評価を受け られるものではなかった。私自身，工場へ通勤するの も，何か悪事をはたらき行くような，らしろめたい気 持にならざるを得ない日が続いた。住民集会では，化学 工場は閉鎖してしまえ，という声をぶっつけられ，法律 でも産業との調和条項は削除されてしまった。

ところで, 今, 化学工場が一斉に操業を停止すると世 の中はどうなるだろう。一時的に生活環境は良くなるに 違いない。けれども, 一方では, 現代の文明生活は混乱 状態に陥ることは避けられないだろう。1973年秋の一連 の石油化学工場の事故にともなら操業停止でさえ大きな 経済的混乱を起した。

染料中間物工業注, 戦後, 染料生産合理化カルテルの 中でわが国に誕生し, ケネディラウンド以後の貿易自由 化の波乗って, 国際分業路線を押し進めながら, 化学 工業の一つとして，世界に市場を拡げてきた。したがっ て, 今, 日本の染料中間物工業が生産を停止すると, 世 界中の染料メーカーが生産に支障をきたすことになる。

また, 染料中間物注農薬, 医薬, ゴム薬や工業用界面 活性剤の原料ともなるので, 国内に晾けるそれらの生産 にも影響をおよぼすことになるに違いない。そうなる と, 市民以色のない服を着ることになり, 農民は農薬を つくれ，と騒ぎだすことになる。だから，染料中間物工 業に従事する化学屋は, やり, 人間生活の拈役に立つ仕 事をしていると考えるべきであろう。

そうなると，化学工場は閉鎖するのではなく，一日も

* スガイ化学工業株式会社

* Sugai Chemical Industry Company Ltd.
早く公害対策の手を打って，安定した生産を続けなけれ ばならないといらことになる。しかし，企業では「もう け」とのかるあいがつねに問題になる。染料中間物工業 は，世界的な規模で集中合理化されつつあるとはいえ， 一般的にはまだまだ多品種少量生産であり, 大規模工業 とはいえない状況である。

染料中間物専業メーカーの資本金は 10 億円 以下の規 模にとどまっている。ところが，この工業の公害対策設 備への投資額は大きく, その比率は全設備投資額に対し て，50\%を超えており，今後ともこの傾向は続くとみ られる。かが国の化学工業における公害対策設備への投 資比率は, 1972 年度 $10.5 \%, 1973$ 年度 $15.8 \%$ であり， 1974 年度は $24.5 \%$ と見込まれている。また, アメリカ における化学工業の公害対策設備への投資額がこのとこ 万年率 50\% の伸びを示しているとはいうものの, 新規 設備投資総額に占める比率は $10 \%$ 前後でしかないこと を考慮すれば，わが国におけるこの工業の公害対策投資 負担がいかに重いかが理解できる。

このことは, 廃水処理施設の專門メーカーから, 手に 負えない水という烙印を押された廃水をかかえているこ とに大きく起因している。すなわち, 染料中間物工業の 廃水の特長をあげると，(1) おもに回分式の生産方式が とられているので, 廃水水質の時系列変動幅が大きいこ と,（2）製造工程では，反応あるいは分離，精製に際し て, 多くの場合水を溶媒として使うので, 廃水中の污濁: 物質の濃度が濃いこと，(3) その廃水中には, スルホン 基やアミノ基などの親水基を持つ芳香族化合物が多種多 様に含まれているので，一般的な生物処理や物理的処理 は困難なこと, 以上の 3 点に要約できる。

したがって，われわれ染料中間物メーカーは，このよ らな廃水を浄化するために, 工業規模が小さいにもかか わらず, 多種類の処理方法を組合せる必要があり, 経済 
的に大きな困難を克服しなければならない。ここでは， その困難を克服するための考え方を三つ提起するととも に, 廃水の実態を述べて, 諸兄のご批判, ご助言を賜る ことにしたい。

\section{I. 水質の変動幅とその縮小}

\section{1. ゆれ動く廃水の污濁物質濃度 廃水処理プラン} ト一流入する原水の負荷濃度, あるい㥜荷量は, 変動 が少ないほどよい処理ができることは明らかである。す なわち，一般に連続操作を行ならプラントは定常状態に おける運転を仮定して設計されているので流入する廃水 のゆれが大きいと，非定常状態における運転をしなけれ ばならなくなり，設計どおりの処理効率が出ないことに なる。

化学工場の稼動㣻一般に 24 時間 稼動である点におい ては染料中間物製造工場の場合も例外ではない。しか し, 生産方式は石油化学の場合と異なり, 多品種少量生 産に適した回分式をおもに採用している。したがって, 各工程から濃厚な濾過廃水が間欠的に排出され, 廃水処 理プラントに流入するので, 廃水の量, 質はともに変動 の幅が大きい。実際，製造プラントから排出される廃水 は, $\mathrm{COD}_{\mathrm{Mn}}$ で $100 \mathrm{ppm}$ 台から $100,000 \mathrm{ppm}$ 台まで, 広、範囲に分布している。これらの廃水は, 通常, 沈砂 槽を経由して原水槽に貯留される。この間に廃水の水質 のゆれ幅は多少小さくなるけれども, 原水槽における平 均滞留時間が 7 時間程度とれたとしても, 原水槽から 4 時間毎にサンプリングした原水の $\mathrm{COD}_{\mathrm{Mn}}$ の標準偏差は 平均值の $30 \sim 35 \%$ はある。すなわち, 原水の $\mathrm{COD}_{\mathrm{Mn}}$ の変動の分布が正規分布するものとして, 仮にその平均 值を $1,000 \mathrm{ppm}$ とすれば, $0 \mathrm{ppm}$ から 2,050 ppm の 範囲にゆれ動いていることになる。

一方, 排出水に関する法的な規制は, 最大值と平均值の 二本立で行なわれている。たとえば，水質污濁防止法に よると, 染料中間物製造工場の排出水については経過措 置期間を過ぎると $\mathrm{COD}_{\mathrm{Mn}}$ 最大值 $260 \mathrm{ppm}$, 平均值 200 $\mathrm{ppm}$ と定めてある。これをみると，排出水のゆれ幅は平 均值に対して高高 $30 \%$ にしなさいということである。

すなわち，信頼限界 $99 \%$ とすれば $3 \delta(\delta:$ 標準偏差） をとる必要があるので, 相詨的標準偏差は 10\% 以下に 抑えなければならないと解釈できる。もしゆれ幅がこれ 以下に圧縮できなければ, 当然最大值規制に適合させる 必要があるので, 平均值は泫れ幅の大きい分だけ低いも のにしなければならない。いま仮に，35\% の相対的標 準偏差を持つ廃水が処理された後も, そのままの割合で ゆれるとすれば，排出水の $\mathrm{COD}_{\mathrm{Mn}}$ 最大值 $260 \mathrm{ppm}$ を
満足させるための平均值は約 $126 \mathrm{ppm}$ でなければなら ないことになる。COD $\mathrm{Cn}_{\mathrm{Mn}}$ の平均值が $200 \mathrm{ppm}$ で良い ところを $126 \mathrm{ppm}$ まで落さなければならないとなると， 廃水処理プラントの建設費や運転経費は大幅に高いもの につくであらう。

したがって, 廃水処理プラントの処理 効率からみて も, 設備コストからみても, 廃水のゆれ幅を縮少するこ とに多少扔金をかけても経済的な廃水処理を期待するこ とができるはづである。

\section{2. 水質変動幅の縮少 一般に, 水質の変動幅を縮} 少するためには, 均一化槽を設置することが行なわれ る。実際のプラントでは, 完全混合槽を 2 槽直列に連ね たものを設置することが多いようである。

染料中間物工場の廃水はランダムに変動するが, 均一 化の設計には周波数応答解析を応用することができる。 ここではその解析については省略することにして，さき にあげた例で, 均一化槽に流入する廃水の $\mathrm{COD}_{\mathrm{Mn}}$ 平均 值が 1,000 ppm で, 標準偏差が 350 ppm のものについ て計算した結果を述べておく。

すなわち，上の上うな原廃水が均一化槽から流出する 際に, 信頼度 $99 \%$ で標準偏差を $100 \mathrm{ppm}$ に縮少しよ うとすれば，第 1 , 第 2 両槽を通じての総平均滞留時間 を約 15 時間とる必要がある。さらに標準偏差を小さく

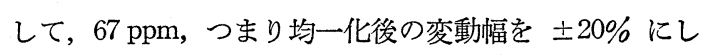
ようとすれば, 約 35 時間の総平均滞 留 時間をとらなけ ればならないことになる。いま, 原廃水の流入量が時間 当り $100 \mathrm{~m}^{3}$ であるとすれば，前者の場合で $1,500 \mathrm{~m}^{3}$ 後者の場合で $3,500 \mathrm{~m}^{3}$ の均一化槽が必要になる。これ を二分割した均一化槽を二槽直列に並べるとして, 高さ $5 \mathrm{~m}$ の円筒形の槽を作った場合, 槽の半径は 7, あるい は $11 \mathrm{~m}$ となり，これを設置するに必要な面積は約 400 , あるいは $1,000 \mathrm{~m}^{2}$ となる。これだけの土地を規模の小 さな染料中間物工場で確保することは容易なことではな い。しかも，その土地が廃水の水質のゆれを小さくする ためにだけ占められるとすれば，多少の㧍金で，という わけにはいかないだろう。

それでは，他にどのような方法があるだろうか。一つ は, $\mathrm{COD}$ 濃度別に原水の貯槽をいくつも持って, 比例混 合する方式, 他の一つは, 濃度かく乱の主要な原因になる 特に濃度の濃い廃水, たとえば $10,000 \mathrm{ppm}$ 以上の廃水だ けを別に分割して貯留し, 他の一般的な濃度の廃水のゅ れを制御するように混合する方式があると考えられる。

これら二つの方法のうち, 前者は排出基準以上の被処 理廃水を平均值まわり $30 \%$ 以下の幅で分割集水するこ とが必要であり, 均一化槽の大ささは小さくなっても設 
置すべき貯槽の数が多くなるので，必ずしも経済的とは いえない。しかも，各濃度段階の貯槽容量 (滞留時間) を決定するためには, 濃度別廃水の量と排水時間帯の厳 密な把握を必要とする。また，年間を通じて生産品種の 切換えもあり，排出時間を一概に規定することができな い現実があるので，この方法は実現不能に近い方法とい わざるを得ない。

後者の方法であれば, $10,000 \mathrm{ppm}$ 以上の濃度の廃水 の量は，およそ全排出水量の $10 \%$ 以下と考えられるの で，貯槽の容量は小さくて済むことになる。もちろん， 濃厚廃水槽が一槽だけでは槽内濃度が不安定で, 変動す るその他の廃水の濃度を調整するのはむつかしい。少な くとも濃度調整用に使用する濃厚廃水法濃度のゅれが 0 でなければならない。したがってこの貯槽は完全混合可 能のものとして, 受入れ, かくはん均一化濃度検定, 放 流の各段階に相当する槽を各 1 基，合計 3 基は持つ必要 がある。

ただし，この方法では，均一化槽ならびに高濃度廃水 の濃度を敏速に把握する必要がある。とくに, 均一化槽 に $\mathrm{pH}$ 調整槽のような敏速な応答調整を期待できれば, 最もコンパクトな濃度均一化システムを組むことが可能 と思われる。

狭い日本では，中小企業ならずとも，土地を有効に使 うべきであると信ずるので，COD 関係の応答時間が短 かい検知システムとフィードバックシステムの開発され る日の一日も早くくることを望みたい。現在のところで は TOD 自動分析器による 3 分間が最も速い検知時間で ある。

\section{II. 廃水処理場で得られる情報の活かし方}

1. 廃水処理という仕事 工場が 24 時間操業して いる限り，廃水処理にも同じシフトが組まれている。と ころが, 処理場の仕事は金にならない，それどころか金 を喰う仕事だからできる限り単純化して，ゆるされるな ら下請けにでも委せよう，というのが廃水処理という仕 事に対する一般的な考え方のようである。

医者は人間の健康状態を診断する手段として，尿の検 査を行なら。これは, 人間の身体の代謝産物が尿として 排せつされるので，これを検查分析することにより，健 康状態に関する多くの貴重な情報が得られるからである ことはいうまでもない。

染料中間物の製造工程では，反応にしろ，分離にしろ 多くの場合水を溶媒として用いる。したがって, 工場の 廃水を調べることは，医者が尿検查をするのと同じこと で，工場における製造工程に関する肝腎な情報を得るこ
とになるはずのものである。だから，われわれの工場で は廃水処理の仕事を，それ程簡単にあしらってしまうわ けにはいかない。

たとえば，染料分子に不可欠なアミノ基の尊入には，

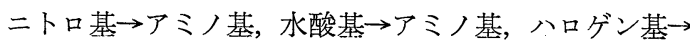
アミノ基などの方法が一般的に用いられる。代表的な方 法であるニトロ基の還元反応では，アニリンや $\alpha$-ナフ チルアミンのような生産量の多い中間物を除けば，多く の場合ほとんぞ水と鉄粉による還元方法が実施されてい る。この方法では，一般に還元生成物は水溶液として酸 化鉄粉と分離した後, 冷却晶出せしめて, 水と口別する ので，口液すなわち廃水中には目的物である芳香族アミ ンとアゾオキシ化合物などの不純物が含まれている。

さらに具体的には, 分散染料 Disperse Yellow 3 な どの中間物, $p-\mathrm{N}$ アセチルアミノアニリンの場合は製 品を口別した後の口液流酸を加えて，アミンを硫酸塩 として酸析し回収しているけれども，なお $10,000 \mathrm{ppm}$ 程度の $\mathrm{COD}_{\mathrm{Mn}}$ に相当するアミン類が廃水中に含まれ ている。また，反応性染料 Reactive Red 1 などの中間

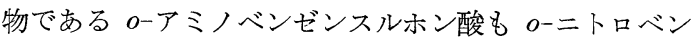
ゼンスルホン酸を鉄粉で還元して製造されているが，そ の製品取出し後の口液には, 約 $25,000 \mathrm{ppm}$ の $\mathrm{COD}_{\mathrm{Mn}}$ に相当するアミン類が含まれている。これらの口液をぺ 一パークロマトグラフィーにかけると，、くつものスポ ットに分離することができるし，定性的には還元反応が らまく行なわれたかどうかもわかる。すなわち染料中間 物の大部分は，本来水溶性であり，おまけに，その製造 工程の溶媒として水を使うことが多いので廃水中には多 くの製造工程に関する情報が含まれている。

ところが，一般的に工程管理として収率の方は各バッ チ毎にチェックされているけれども，廃棄物の方は何か 特別の事情でもない限り，工程管理の目からこぼれ落ち ているのが，現状である。収率が標準值に対して $10 \%$ 程度ばらつくとしても，標準值が $80 \%$ である場合, 口 大は $12 \%$ 加 $28 \%$ まで，20\% を平均值として相対的 に $\pm 40 \%$ もの変動幅を持つことになる。さらに，標準 収率が 90\% の場合は，口ス率は 1\% から 19\% まで 10\%を平均值として, 相対的に $\pm 90 \%$ もばらつくこと になる。実際には，収率が高くなればなる程，変動幅の 相対值は小さくなるし，ばらつきの分布も正規分布では なくなるので，上記のようなことはないけれども，廃水 をちェックした方が工程からの情報が増幅したかたちで 得られることは間違いない。また，現状ではトラブルの 生じた後で原因解明を目的とし物質収支をみたいと思っ ても廃菓物の類はどこかに行なってしまっている。した 
がって, 工程管理として収率だけをチェックするのでは 片手落ちといらもので, 本来化学工業では, その工程管 理は物質収支を明らかにすることによってなされるべき であるといら原則からも逸脱することになる。

製品の品質や収率をチェックすることは, 体重や血圧 を測っているようなもので, 確かに健康状態を示すバロ メーターの役割ははたしているだろらが, 何か変調が生 じたときの原因が解る情報として役立つほどものではな い。ただし, 廃水の分析も $\mathrm{COD}_{\mathrm{Mn}}$ を測定するだけで は, 情報が大雑把すぎて, 詳かな工程管理の役には立た ない。医者が尿の色, 清濁, 比重, タンパク, 糖を測定 し, さらに分子ふるいを用いて詳細な成分追究を試みて いるように，われわれも，できれば，廃水中に存在する 一つ一つの有機物について，何がどれだけ含まれている というところまで分析しなければ，腎臟が悪いのか肝臟 が悪いのか，はっきりしないことになる。

ここまで考えると, 廃水処理という仕事は, 単に処理 場に受け入れた廃水を処理して排出水の水質を目標值内 に収めるようにするとか, 設備が常に正常に作動するよ うに保守点検するとかいらことだけでなく, 工場の肝腎 かなめのところを掌握する仕事であり, 貴重な情報を製 造現場に向ってフィードバックする積極的な働きを期待 されるべき重要な仕事だということになる。また, 廃水 の内容を詳細に把握してこそ, はじめて適切な処理が可 能になるというものである。

\section{2. 工程管理としての廃水分析 ところで，どうす} れば，工程管理に役立つ情報まで把めるようになるだろ らか。染料中間物廃水の中の各種有機物が総て知りつく されている状況ではない。はたして，それが簡単に把め るようになるだろうか。

従来, 染料中間物の定量分析にはジアゾ化法, カップ リング法の二法が主に採用されてきた。これでは，アミ ノ基, 支るいは水酸基を持った芳香族化合物を総括的に 定量するだけで，異性体などに関する情報を得ることが 困難で, $\mathrm{COD}$ や BOD を測定しているのと基本的には 変りがない。

分離定量の分析方法として優れているガスクロマトグ ラフィーは, 染料中間物が多くの場合水溶性で, しかも その蒸気圧が低いため, 利用しにくい状態にあった。異 性体をはじめとする不純物についての定量的な情報を得 ようとすれば, ペーパークロマトグラフィーや薄層クロ マトグラフィーで展開したものを抽出分離した後定量す るか, カラムクロマトグラフィーで分離しなければなら ない状況であった。これでは, 時間と手間がかかりすぎ て, 工程管理用のルーチン分析にはとても使えない。
時間と手間の比較的かからない方法としては, IR や UV 吸光分析法が使えることもあるが, 混在する不純物 の数が多いと分析不能で, 感度も満足すべきところまで は達していない。

現在のところ，急速に普及しつつある高速液体クロマ トグラフィーが，われわれの目的をかなえてくれる分析 方法となる可能性を持っている唯一のものである。しか し, 高速液体クロマトグラフィーといえども, 各種の廃 水が混合されたものを分析するのは, 試料があまりにも 複雑すぎて, お手上げであろう。実験の結果も, よほど 田純な廃水でないと分離が不十分であったり, 機械が故 障してしまうことが多い。だからといって，あまり複雑 な前処理が必要になると廃水のルーチン分析には役立た ない。

幸いにして, 化学工場では人体とは異なって手術まで しなくても比較的簡単に各ユニットから試料を採取する ことができる。すなわち, 廃水の分析も各種の工程から 排出されたものが混合される以前に，それぞれの工程の 廃水としてサンプリングすることは可能である。この段 階の廃水でも現在の高速液体クロマトグラフィでは手に 負えないものが多いが，それはまだ高速液体クロマトグ ラフィーシステムの開発の歴史が浅いためであろう。こ の分析法に関する研究集中度が世界的にみても高い現状 からすれば，やがてわれわれの期待に添える機能を持つ 日がくると思われる。

それにしても分析の原則からすれば，試料は各工程毎 の廃水を独立に取り扱うべきであろう。その分析結果を 製造工程管理に活かすのであれば，なにも廃水処理の仕 事とは関係ないではないか，との指摘もあろう。だがそ の分析結果は, 廃水処理場にとっては, 受入れ原料に関 する貴重な情報でもある。とくに, 原料組成に変動があ る廃水を生物的に処理しようとする場合は, 廃水処理工 程を管理するための情報として欠かすことができないも のである。

また, 排出水の水質規制值のうち, 有機化合物に関連 のあるものは, $\mathrm{COD}_{\mathrm{Mn}}, \mathrm{BOD}_{5}$, 油分, $\mathrm{SS}$, 有機リンと なっているが, その量的規制の進行にともなって, 必ず 特定の有機物について質的な規制が追加されてくると考 えられる。これは, 生活環境保全の立場からみれば当然 の方向ではないだろらか。ともかく将来あるべき方向に 添うためには, 是非廃水処理の担当部署が排出水の水質 について可能な限り詳しい情報を把握すべきであり, そ のためにも原廃水に関する内容を刻々と把えなければな らないと考える。その結果が，製造工程の管理にも廃水 処理工程の管理にも活かされて, はじめて染料中間物製 
造工業も真にファインケミカル工業の仲間に加わること 化合物が含まれている。COD $\mathrm{C}_{\mathrm{Mn}}$ の比率が大きいものや ができることになる。 $\mathrm{BOD}_{5}$ の比率の大きいものなど, 酸素要求量の面からみ

工程管理のための廃水分析，そ の道は険しく，永いであろうけれ ども, 水に溶存している物質を分 析する技術として, 高速液体ク口 マトグラフィーは大きな光明を投 げかけてくれるように思われる。 もちろん, IR や UV 吸光分析 の分析感度が上がることも大事で あり, 分析技術の向上は廃水処理 の経済性を追求する上において, 不可欠の要素である。かつて, 近 代的な品質管理の導入は生産性の 向上を通して, 企業に大きな経済 的メリットをもたらした。ちなみ に, 当社では廃水処理担当部門を 水質管理班と呼んでいる。

\section{III. 染料中間物の廃水を 処理する技術}

1. 染料中間物の廃水 すで に，染料中間物製造工場の廃水に ついては，その水質，負荷量のゅ れが大きいこと, 工程管理上の貴 重な情報が潜在していることを記 した。また，水質に関する詳しい 情報を把えてこそ，廃水処理施設 の合理的な管理運営ができること にもふれた。廃水処理の方法を選

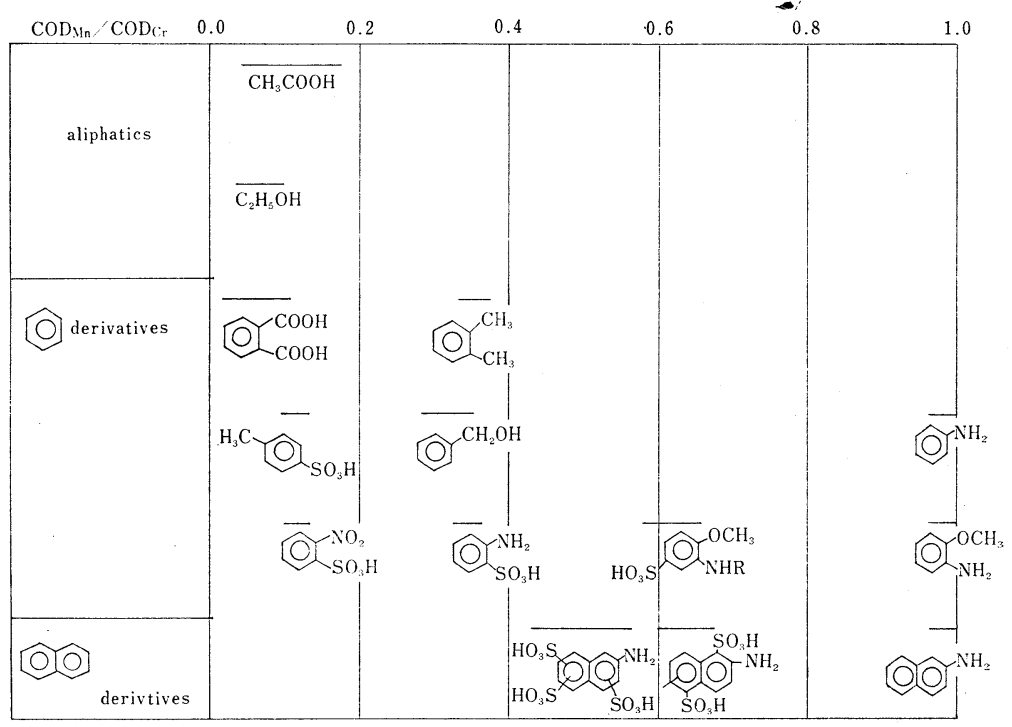

図 1 染料中間物廃水に含まれる有機物の $\mathrm{COD}_{\mathrm{Mn}} / \mathrm{COD}_{\mathrm{Cr}}$

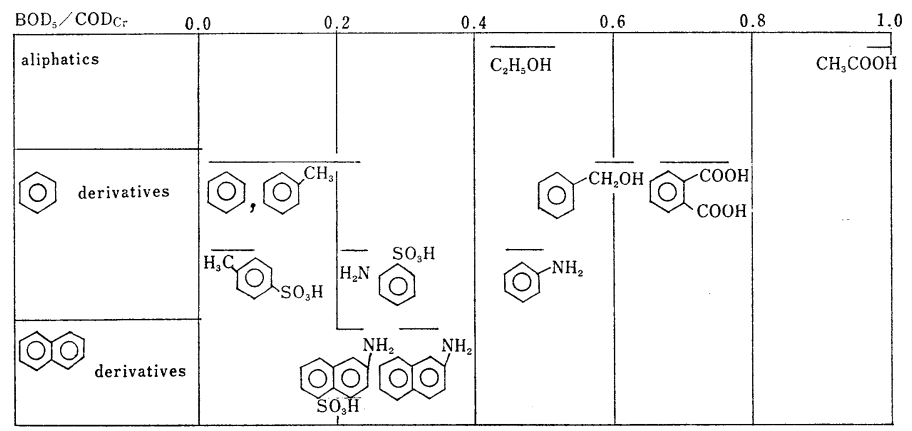

図 2 染料中間物廃水に含まれる有機物の $\mathrm{BOD}_{5} / \mathrm{COD}_{\mathrm{C}}$ 択決定する際，その廃水の性質を本質的に把えることは 重要な仕事の一つでもある。

ところで, 現実の問題として水質規制が $\mathrm{COD}_{\mathrm{Mn}}$ や $\mathrm{BOD}_{5}$ の数值をもって行なわれているので, 廃水中に含 まれている各種の有機物がそれぞれどの程度の酸素要求 量を持っているかを知っておかねばならない。近い将来 TOD が規制対象になる可能性もあるが，少なくとも環 境問題が国際的視野で議論されている昨今であるから， 諸外国で採用されている $\mathrm{COD}_{\mathrm{Cr}}$ の值との関連も知って おく必要がある。数多くの有機化合物について，すでに データが発表されているが，染料中間物の類については 比較的データがそしい。そこで，われわれが調べたデー タのいくつかを図にまとめてみた。

染料中間物の製造段階では, 廃水中にアルコール類, カルボン酸類, スルホン酸類, アミン類など各種の有機
てもさまざまである。

図をみると, $\mathrm{COD}_{\mathrm{Mn}} / \mathrm{COD}_{\mathrm{Cr}}$ はカルボン酸類, アル コール類は小さく 0.1 前後, アミン類は 0.6 以上の比 較的大きな值になる。また，一般的にスルホン基が導入 されると，この比が小さい方へシフトする傾向にある。 たとえば，アニリンやナフチルアミンはほぼ1である が，o-アニリンスルホン酸やナフチルアミンスルホン酸 類は $0.4 \sim 0.6$ である。一方, $\mathrm{BOD}_{5} / \mathrm{COD}_{\mathrm{Cr}}$ はカルボ ン酸類, アルコール類の值が大きく 0.5 以上, アミン 類は 0.5 以下になる傾向がある。スルホン基の影響は $\mathrm{COD}_{\mathrm{Mn}} / \mathrm{COD}_{\mathrm{Cr}}$ の場合と同様に小さい值へ向ってシフ トする形で現われる。

このような成分を含む廃水を処理技術の面からながめ ると，一筋縄ではいかないことが容易に推測できるであ ろう。総合的な廃水処理法としては, 物理的方法, 化学 
的方法, 生物的方法があるけれども，そのうちのどれか 一つの方法で片ゔけてしまうわけにはいかないというこ とである。たとえば, スルホン基のついていないアルコ 一ル類やカルボン酸類は生物的方法で容易に処理できる が，アミン類やスルホン基を持った化合物は生物的方法 を用いて処理することは容易でないといえる。これらの 化合物の処理には, 凝集沈でん法, 膜口過法, 樹脂や活 性炭による吸着法などの物理的方法か, 燃焼法, オジン 酸化法, 光酸化法, 各種薬剂による酸化分解法, あるい はホルマリン縮合による樹脂化などの化学的方法を採用 せざるを得ない。ところが，最も一般的な凝集沈でん法 は，染料中間物の段階では染料に較べて分子量が小さい 上に親水性が強く，あまり効率的な方法とはいえない。 燃焼法をはじめとする酸化分解法は廃水浄化の点では優 れた方法であるが，経済的に桁はずれのコストがかか る。その他の方法も一長一短ありで, 染料中間物廃水の 処理技術として決定的なものはないといっても過言では あるまい。したがって, 現在の時点では, 廃水をいくつ かの種類に類別して, それぞれの廃水に適した処理方法 を採用せざるをえない状況にある。これでは設備費も割 高だし, 運転管理も人手を多く要するので, 決して経済 的な廃水処理であるとはいえない。

2. 染料中間物廃水を処理するための技術 廃水処 理費用を技術的な面から小さくする方法として一般的に 考えられるのは，第 1 に処理すべき廃水が出なくなるよ うに製造工程そのものにメスを入れて改善していく方法 と, 第 2 に廃水を有価物に転換する方法の二つである う。環境保全の立場から考えると, 理想的にはクローズ ドシステムの確立ということになり，第 1 の方法む第 2 の方法も, その理想に近づけるという点からも大いにそ の実現へ向けて努力すべき方法である。

ところが, 染料中間物工業は多品種少量生産の悲しさ で，改善すべき工程は山程ある。一つの製品を製造する のに 10 工程あるとすれば，数十種類の 製品を製造する 工程の数は数百におよぶ。ある大手総合化学会社の国内 特許公開件数は,第 2 産業部門についてみると, 年間数百 件でその中には新製品開発に関するものが多くみられる から規模の小さな染料中間物工業で数百の工程改良を成 しとげるには 10 年といら単位が必要なように思われる。 しかも，環境対策問題は水だけでなく，産業廃衰物，大 気, 悪臭と広い分野に及んでいる。さらに, 研究部門に は新製品開発のテーマが重くのしかかっているといった 具合である。

一方, 生活環境基準をきびしくするスピードは緩む気 配すらなく、工場を取り囲む住民の声も悠長ではない。
理想的には第 1 の方法でこの問題を解決すべきことが明 白であっても，世間がそれを待ってはくれない。むし ろ, 工程改善が追いつかないので, 環境污染を大きく引 き起す製品の製造は思い止まるか, 生産規模を縮少せざ るを得ないというのが実状できる。

第 2 の方法も，製造品目が多岐にわたるので，回収す べき品物の数は多くても量が少なく,なかなか経済的な バランスがとれるところまでは到らない。しかし資源不 足の状況が深刻化していることからすれば，何とかして 物を捨てないようにしなければならない。その点では, 生物処理によって生じた污泥は有機質肥料にでも使える 可能性がある。

ところが今のところ生物処理に適した廃水の量はごく 限られており, 染料中間物工業の廃水は大部分スルホン 基を持った芳香族化合物がその污染源となっているの で，そのままの形で有価物を回収することは容易ではな い。そこで，スルホン基をはずしてしまらことを考えて みてはどらだろらといらことになる。理論的には, 酸触 媒の存在下でスルホン基の加水分解は可能である。

スルホン酸自身も触媒となるし, 加水分解によって生 じる硫酸す触媒となる。さらに, 製品としてスルホン酸 類を取り出す工程には，酸析法が採用されることが多、 ので, その廃水中には塩酸亡か硫酸が含まれているのが 普通である。実際, 製造工程でも芳香族の配向性をかわ すために，スルホン基の加水分解を行ならことはしばし ばみられる。

たとえば，染料中間物として重要な位置を占めている J 酸 (6-アミノナフトール-3-スルホン酸) の製造で は, トビアス酸 (2-アミノナフタレン-1-スルホン酸) をスルホン化して，2-アミノナフタレン-1,5,7-トリス ルホン酸にした後, 1-位のスルホン基を加水分解する工 程が含まれているし，1,7-クレーブ酸（1-アミノナフタ レン-7-スルホン酸) の製造では $\alpha$ ナフトールをスルホ ン化して, $\propto$-ナフトールジスルホン酸とした後, 加水 分解して 1-ナフトール-7-スルホン酸にする工程が含ま れているといった具合である。なお，これらの加水分解 反応は, 酸濃度が $20 \sim 30 \%$ で反応温度は $70 \sim 110^{\circ} \mathrm{C}$ と いら条件の下で行なわれている。また， $\beta$-ナフトールの 製造時には，スルホン化工程で副生する $\alpha$-ナフタレン スルホン酸を加水分解してナフタレンを回収することも 行なわれている。

したがって, 廃水中に污濁物質として含まれている芳 香族スルホン酸類を加水分解して水溶性をなくし, 油水 分離, あるいは固液分離することは不可能ではないと考 えられる。ただ, 反心速度を実用的なところまで速くし 
ようとすれば，加圧高温反応を行なう必要があるのが大 きな欠点になる。

この久点をカバーするためには, 濃度の希薄なスルホ ン酸類を低温ですみやかに加水分解できる触媒を開発す る必要がある。いま，この目的にかなら触媒があるとは いえないけれども，強いていえばトリフルオロメタンス ルホン酸のような強い酸触媒が参考になる。トリフルオ ロメタンスルホン酸そのものでは，廃水処理にそのまま 適用できない使用上の制約がある。イオン交換樹脂は物 理的な吸着力も働き, 酸触媒として使われることもある が，既存のものではわれわれの目的を達成する用はなさ ない。理想的には, 強力な固体触媒を開発して, 廃水が その充てんカラムを通過するだけで加水分解できてしま らよ5にすることである。多少加熱の必要が生じるとし ても, 処理の困難な廃水にしばしば適用される廃液燃焼 処理法に較べれば，加水分解反応のために必要な熱エネ ルギー量はかなり少ないものと期待できるだろう。また この方向でスルホン酸類を含む廃水の処理ができれば， 加水分解終了物は水に溶けにくくなるので回収が容易に なる。たとえば，トルエンスルホン酸を $20,000 \mathrm{ppm}$ 含 む廃水 10 トンが加水分解されると, トルエンが $108 \mathrm{~kg}$ 生成する。トルエンの水に対する溶解度はほとんど無視 できるので, $100 \mathrm{~kg}$ 程度のトルエンは回収できるはづ である。染料中間物によく使われるナフトールの類だ と, トルエンより一桁上の単価であるから, この回収で 経済的メリットもいくら期待することができるようにな ろう。

もし, 加水分解後の回収, 再使用が困難であったとし ても, 経済的な生物処理を効果的に使えるようになるで あろらし, 活性炭処理などの効率も大幅に向上できる。

要するに, 性能のよいスルホン基加水分解用触媒の開 発は染料中間物工業にたずさわる化学屋の夢であり, 義 務であるともいえるのではなかろらか。

\section{IV. おわりに}

染料中間物工業というものをとくに定義しないで筆を 進めてきたが，つぎのような特長を持った廃水をかかえ ているのが染料中間物工業といえるだろう。すなわち, その廃水は (1) バッチ方式の生産体系をとっていること が多いので，廃水水質の時系列変動幅が大きい。(2) 製 造工程では, 反応に際しておもに水を溶媒として使用す るので, 廃水は製造工程の様態を如実に反映している。

（3）その廃水中には，スルホン基などの親水基を持つ芳 香族化合物が多種多㥞に含まれているので，一般的な物 理処理や生物処理が困難である。

したがって，この廃水を浄化するに法，工業規模が小 さい割に多種類の処理方法を組み合わす必要があり，経 済的に大変困難がある。ここでは，その困難を克服する ための考え方としてつぎの三点を提起した。すなわち，

（1）原廃水の水質変動幅を縮小することによって廃水処 理施設の規模を小さくし, かつ効率を上げるために, 速 やかに応答できる酸素要求量の検知フィードバックシス テムの開発を進めること。(2) 原廃水に含まれている製 造工程に関する情報を製造工程管理に活かすことによっ てメリットを生み出す方向を念頭におき, 高速液体ク口 マトグラフィーの活用をはかること。(3) 水系のクロー ズド化をはかる方向で製造工程の改革を行なら方向と廃 水から有価物を回収する方向があるが，染料中間物廃水 の最大の污染源と考えられる芳香族スルホン酸を加水分 解して, 有価物を回収すること。

これらは，いずれもまだ発想の段階であり，険討不充 分のところが多い。しかし，環境規制を厳しくする社会 的圧力が高まる中で一人でも多くの方からご協力を得 て，実現できるものは一日でも早く実現したいとの願い をこめて，あえて文章にしてみた次第である。

(昭和 49 年 12 月 28 日受理) 